\title{
Pengaruh Tingkat Kematangan dan Suhu Penyimpanan Terhadap Mutu Buah Terong Belanda (Cyphomandra betacea)
}

\author{
Influence of Maturity Stage and Storage Temperature on Fruit Quality of Tamarillo \\ (Cyphomandra betacea)
}

Elisa Julianti ${ }^{1}$

Diterima 8 Desember 2010/Disetujui 1 Maret 2011

\begin{abstract}
Tamarillo is a perishable fruit. To ensure the highest fruit quality tamarillos must be harvested at an appropriate stage of maturity. In the present study, effects of maturity stage and storage temperature on the physical and chemical characteristics of tamarillo were determined. The fruits were harvested at three stages i.e. immature, mature, and ripe and kept in cold storage at $10^{\circ} \mathrm{C}$ and at ambient conditions $\left(28 \pm 2{ }^{\circ} \mathrm{C}\right)$ for a period of 15 days. The fruits were evaluated for quality variables at harvest and after 5, 10 and 15 days of storage. During investigation period fruit quality variables changed according to stage of harvest. An increase in weight loss, total soluble solid (TSS) was observed with the advancement of maturity stages and storage period. In contrast, vitamin $C$ content and titratable acidity followed a linear decline with storage and advancement of maturity stages. Fruits harvested at optimum stage retained maximum TSS, titratable acidity and sensory quality (color, flavor and texture) score during storage of 10 days at ambient and 15 days at cold temperature.
\end{abstract}

Key words : Tamarillo, maturity stage, storage, fruit quality

\section{PENDAHULUAN}

Terong belanda (tamarillo) merupakan buah dari family Solanacea dan berasal dari daerah sub tropis. Saat ini buah terong belanda banyak dibudidayakan oleh petani di daerah Tanah Karo Sumatera Utara. Ada tiga tipe terong belanda yang banyak ditanam, didasarkan pada warna kulit dan daging buah (pulp) yaitu merah, merah tua dan kuning. Indeks kematangan buah yang terbaik untuk terong belanda adalah warna kulit dan daging buah (pulp). Indikator lainnya yang berhubungan dengan warna kulit adalah perubahan kekerasan, kandungan juice dan total padatan terlarut. Selama proses pemasakan terjadi perubahan warna kulit. Pada buah dengan warna kulit merah tua, perubahan kulit dari hijau menjadi ungu tua yang disebabkan oleh klorofil dan antosianin hingga akhirnya berubah menjadi merah. Pada jenis ini buah sebaiknya dipanen pada saat warna kulit ungu tua. Jika buah dipanen pada saat masih hijau, nilai organoleptik aroma, kandungan juice, total padatan terlarut dan warna kulit setelah masak menjadi lebih rendah dibanding buah yang dipanen pada saat telah berwarna ungu tua (El-Zeftawi et al., 1988; Heatherbell et al., 1982).

Terong belanda (tamarillo) sebagaimana buahbuahan lainnya merupakan komoditi yang sangat mudah rusak terutama karena kondisi penyimpanan yang tidak baik seperti suhu dan komposisi udara ruang penyimpanan. Penyimpanan buah pada suhu rendah dapat memperlambat kecepatan reaksi metabolisme sehingga akan memperpanjang umur simpannya. Dari hasil penelitian Espina dan Lizana (1991, diketahui bahwa buah terong belanda yang dipanen pada stadia masak (kulit berwarna merah), $\mathrm{pH}$ juice, total asam dan total padatan terlarutnya tidak mengalami perubahan setelah 15 hari disimpan pada suhu $0^{\circ} \mathrm{C}$ atau 35 hari penyimpanan pada suhu $7^{\circ} \mathrm{C}$, tetapi dari hasil penelitian El-Zeftawi et al. (1988) ditemukan bahwa buah terong belanda yang dipanen pada stadia matang (mature) yaitu pada saat kulit berwarna ungu tua, maka buah masih dapat melanjutkan proses pemasakan secara normal. Penelitian ini bertujuan untuk mengetahui pengaruh tingkat kematangan dan suhu penyimpanan terhadap mutu buah terong belanda selama penyimpanan.

\section{BAHAN DAN METODE}

Bahan yang digunakan adalah buah terong belanda yang diperoleh dari petani di daerah Tanah Karo, dan diangkut ke lokasi penelitian di Laboratorium Ilmu dan Teknologi Pangan Fakultas Pertanian USU pada hari yang sama dengan pemanenan. Buah terong belanda yang digunakan adalah buah dengan 3 tingkat kematangan yaitu buah terong belanda yang mentah yaitu buah yang berwarna hijau, buah yang matang (mature) yaitu

\footnotetext{
${ }^{1}$ Program Studi Ilmu dan Teknologi Pangan Fakultas Pertanian USU Medan

Jl.Prof.A.Sofyan No. 3 Kampus USU Medan

Fax : 061-8211924, email : elizayulianti@yahoo.com, HP.081361033610
} 
buah dengan tingkat kematangan optimum dengan warna kuning kemerahan dan tekstur yang masih keras, serta buah yang masak (ripe), yaitu buah yang sudah berwarna merah dan tekstur yang sudah agak lunak. Bahan lainnya adalah bahan kimia untuk analisis kadar vitamin $\mathrm{C}$ dan total asam.

Alat yang digunakan adalah stoples sebagai wadah penyimpanan, lemari pendingin, alat pengukur konsentrasi $\mathrm{O}_{2}$ (cosmotector tipe XPO 318), alat pengukur konsentrasi $\mathrm{CO}_{2}$ (cosmotector tipe XP 314) dan alat-alat gelas untuk analisa kimia.

Penelitian dilakukan dengan menggunakan Rancangan Acak Lengkap (RAL) Faktorial dengan 2 faktor, yaitu tingkat kematangan sebagai faktor I dengan 3 taraf perlakuan yaitu $\mathrm{K}_{1}=$ buah yang mentah, $\mathrm{K}_{2}=$ buah matang dan $\mathrm{K}_{3}=$ buah yang masak. Faktor II adalah suhu penyimpanan terdiri dari 2 taraf, yaitu $\mathrm{T}_{1}=10{ }^{\circ} \mathrm{C}$ dan $\mathrm{T}_{2}=28 \pm 2^{\circ} \mathrm{C}$ (suhu ruang). Setiap perlakuan dibuat dalam 3 ulangan. Pengamatan terhadap mutu buah terong belanda dilakukan pada hari ke 0, 5, 10 dan 15 .

Variabel mutu yang diamati adalah susut bobot, kadar air (AOAC, 1995), kadar vitamin C (Sudarmadji et al., 1989), total asam tertitrasi (Ranganna, 1978), total padatan terlarut (dengan hand refractometer), kekerasan dengan teksturometer dan dinyakatan dalam $\mathrm{kg} / \mathrm{mm}$, nilai warna dengan uji deskripsi (hijau $=1$, hijau kekuningan $=2$, merah kekuningan $=3$, merah $=4$ dan merah kecoklatan $=5$ ), serta nilai kesukaan aroma dan tekstur dengan uji hedonik skala 1-5 (Sangat tidak suka - sangat suka).

Laju respirasi buah terong belanda dilakukan pada ketiga tingkat kematangan buah dengan sistem tertutup (Deily dan Rizvi, 1981). Pengamatan dilakukan terhadap perubahan konsentrasi $\mathrm{O}_{2}$ dan $\mathrm{CO}_{2}$ dan laju respirasi dinyatakan dengan laju konsumsi $\mathrm{O}_{2}$ dan laju produksi $\mathrm{CO}_{2}$ dalam $\mathrm{ml}$ $\mathrm{kg}^{1} \mathrm{jam}^{-1}$.

\section{HASIL DAN PEMBAHASAN}

\section{Laju Respirasi Buah Terong Belanda}

Laju respirasi buah terong belanda yang ditunjukkan oleh laju konsumsi $\mathrm{O}_{2}$ dan laju produksi $\mathrm{CO}_{2}$ disajikan pada Tabel 1 dan Gambar 1. Tabel 1 menunjukkan bahwa semakin tinggi tingkat kematangan buah, maka laju respirasi akan semakin meningkat, tetapi setelah buah mencapai kematangan optimum laju respirasi akan kembali menurun. Beberapa penelitian terhadap buah-buahan tropis juga menunjukkan hasil yang sama, yaitu semakin tinggi tingkat kematangan dan suhu penyimpanan maka laju respirasi akan semakin meningkat (Riviera-Lopez et al., 2005; Gayosso-Garcia Sancho, 2010 ; Azzolini et al., 2005).

Pada Gambar 1 terlihat bahwa selama penyimpanan terdapat pola perubahan laju respirasi yang hampir sama untuk ketiga tingkat kematangan buah, kecuali pada buah yang matang yang disimpan pada suhu ruang, dimana laju respirasinya meningkat hingga hari ke-8 penyimpanan. Tetapi secara umum tidak terlihat adanya perubahan laju respirasi yang mencolok pada ketiga tingkat buah terong belanda selama penyimpanan, yang menunjukkan bahwa buah terong belanda tergolong buah non klimaterik (Kader, 2001).

Semakin tinggi tingkat kematangan dan suhu penyimpanan, maka nilai RQ (respiration quotient) akan semakin rendah. Pada suhu $10{ }^{\circ} \mathrm{C}$, nilai RQ buah terong belanda pada ketiga tingkat kematangan $>1$, tetapi pada suhu ruang nilai RQ buah yang mentah dan masak $<1$. Nilai RQ $>1$ menunjukkan bahwa substrat untuk respirasi adalah asam-asam organik, sedangkan nilai RQ $<1$ dapat disebabkan oleh proses oksidasi yang belum tuntas, $\mathrm{CO}_{2}$ yang dihasilkan digunakan untuk proses sintesis atau substrat yang dioksidasi mempunyai perbandingan antara oksigen dan karbon yang lebih kecil dari heksosa (Winarno dan Wirakartakusuma, 1981).

Tabel 1. Laju respirasi dan nilai RQ buah terong belanda

\begin{tabular}{lcccccc}
\hline & \multicolumn{3}{c}{ Suhu $10{ }^{\circ} \mathrm{C}$} & \multicolumn{3}{c}{ Suhu $28 \pm 2{ }^{\circ} \mathrm{C}$} \\
\hline & Mentah & Matang & Masak & Mentah & Matang & Masak \\
\hline $\begin{array}{l}\text { Laju Konsumsi } \mathrm{O}_{2} \\
\left(\mathrm{ml} \mathrm{kg}^{-1} \text { jam }^{-1}\right)\end{array}$ & $9.34 \mathrm{e}$ & $11.00 \mathrm{~d}$ & $7.61 \mathrm{f}$ & $21.68 \mathrm{~b}$ & $33.64 \mathrm{a}$ & $17.63 \mathrm{c}$ \\
$\begin{array}{l}\mathrm{Laju} \mathrm{Produksi} \mathrm{CO}_{2} \\
\left(\mathrm{ml} \mathrm{kg}^{-1} \text { jam }^{-1}\right)\end{array}$ & $13.23 \mathrm{e}$ & $15.12 \mathrm{c}$ & $7.81 \mathrm{f}$ & $14.93 \mathrm{~d}$ & $47.55 \mathrm{a}$ & $17.54 \mathrm{~b}$ \\
$\mathrm{RQ}$ & 1.42 & 1.37 & 1.03 & 0.69 & 1.41 & 0.99 \\
\hline
\end{tabular}

Keterangan : Angka di dalam tabel merupakan rataan dari 3 ulangan. Angka yang diikuti dengan huruf yang berbeda pada baris yang sama menunjukkan pengaruh yang berbeda nyata pada taraf $5 \%$ dengan uji Tukey 


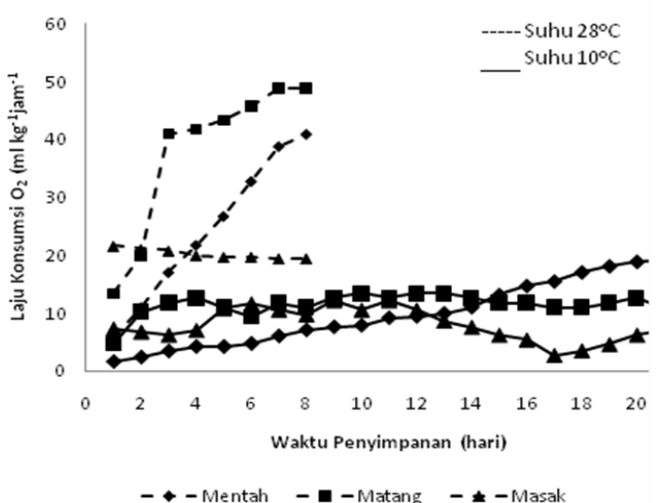

(a)

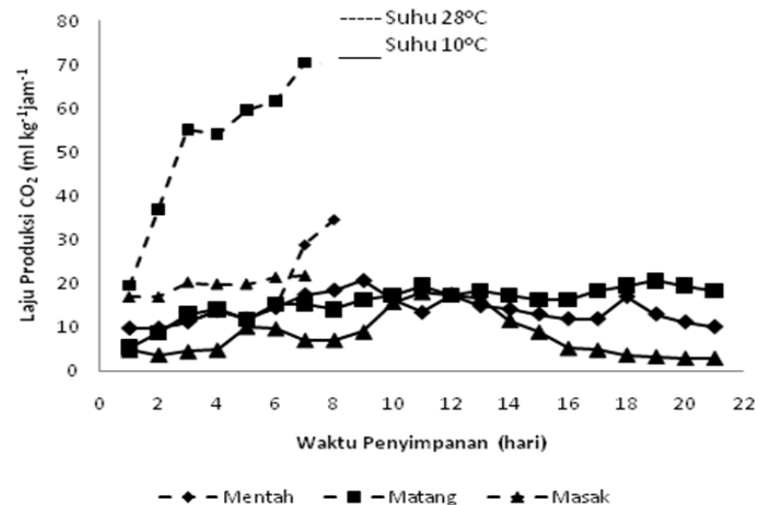

(b)

Gambar 1. Laju konsumsi $\mathrm{O}_{2}$ (a) dan laju produksi $\mathrm{CO}_{2}$ (b) dari buah terong belanda dengan 3 tingkat kematangan selama penyimpanan pada suhu ruang $\left(28 \pm 2{ }^{\circ} \mathrm{C}\right)$ dan suhu $10{ }^{\circ} \mathrm{C}$.

Pengaruh Tingkat Kematangan dan Suhu Penyimpanan Terhadap Mutu Buah Terong Belanda

Perbedaan tingkat kematangan buah pada saat panen menyebabkan terjadinya perbedaan mutu buah terong belanda selama penyimpanan seperti terlihat pada Tabel 2 dan Tabel 3. Semakin tinggi tingkat kematangan buah maka kadar air, total padatan terlarut, nilai warna serta kesukaan terhadap aroma dan tekstur buah akan semakin meningkat, tetapi kandungan vitamin $\mathrm{C}$, total asam dan nilai kekerasan akan semakin menurun. Pada suhu dingin semua nilai variabel mutu buah terong belanda lebih tinggi daripada suhu ruang kecuali nilai warna. Penyimpanan buah akan menyebabkan terjadinya penurunan nilai semua variabel mutu buah terong belanda yang diamati, kecuali nilai skor warna. Hasil yang sama juga diperoleh pada buah persimon (Ramin and Tabatabaie, 2003), tomat (Karki, 2005; Manorezzaman et al., 2008) dan buah ivorian gnagnan (N’Dri et al., 2010).

\section{Susut Bobot}

Selama penyimpanan terjadi kehilangan berat buah terong belanda pada ketiga tingkat kematangan buah seperti terlihat pada Gambar 2 . Susut bobot selama penyimpanan disebabkan oleh proses transpirasi dan respirasi yang menyebabkan terjadinya kehilangan air (Wills et al., 1981). Buah yang mentah memiliki susut bobot yang lebih rendah daripada buah yang masak. Susut bobot buah pada suhu dingin lebih rendah daripada suhu $28 \pm 2{ }^{\circ} \mathrm{C}$. Hasil yang sama juga terdapat pada buah peach (Gupta dan Jawandha, 2010).

Tabel 2. Pengaruh tingkat kematangan dan suhu penyimpanan terhadap variabel mutu buah terong belanda selama penyimpanan

\begin{tabular}{|c|c|c|c|c|c|c|c|c|}
\hline \multirow{3}{*}{ Parameter Mutu } & \multirow{3}{*}{$\begin{array}{c}\text { Tingkat } \\
\text { Kematangan }\end{array}$} & \multicolumn{7}{|c|}{ Lama Penyimpanan (Hari) } \\
\hline & & \multicolumn{4}{|c|}{ Suhu $10^{\circ} \mathrm{C}$} & \multicolumn{3}{|c|}{ Suhu $28 \pm 2{ }^{\circ} \mathrm{C}$} \\
\hline & & 0 & 5 & 10 & 15 & 5 & 10 & 15 \\
\hline \multirow[t]{3}{*}{ Kadar Air (\%) } & Mentah & 87.36 & 86.18 & 84.69 & 83.04 & 84.34 & 82.68 & 81.85 \\
\hline & Matang & 87.95 & 86.38 & 84.71 & 84.19 & 84.61 & 82.85 & 80.99 \\
\hline & Masak & 88.06 & 86.77 & 85.12 & 84.94 & 85.21 & 81.73 & 80.75 \\
\hline Vitamin & Mentah & 38.10 & 37.10 & 37.10 & 36.50 & 35.20 & 33.20 & 26.40 \\
\hline \multirow{2}{*}{$(\mathrm{mg} / 100 \mathrm{~g})$} & Matang & 35.20 & 35.50 & 35.20 & 33.20 & 34.20 & 29.80 & 24.45 \\
\hline & Masak & 26.40 & 26.70 & 25.80 & 22.50 & 25.45 & 19.98 & 17.50 \\
\hline \multirow[t]{3}{*}{ Total Asam (\%) } & Mentah & 0.86 & 0.87 & 0.86 & 0.76 & 0.91 & 0.73 & 0.59 \\
\hline & Matang & 0.67 & 0.59 & 0.61 & 0.56 & 0.52 & 0.54 & 0.45 \\
\hline & Masak & 0.55 & 0.52 & 0.43 & 0.38 & 0.41 & 0.34 & 0.27 \\
\hline Total Padatan & Mentah & 5.50 & 6.00 & 5.50 & 5.50 & 5.50 & 6.00 & 5.50 \\
\hline \multirow[t]{2}{*}{ Terlarut $\left({ }^{\circ} \mathrm{Brix}\right)$} & Matang & 8.50 & 8.50 & 9.00 & 8.50 & 8.00 & 7.50 & 6.50 \\
\hline & Masak & 11.00 & 11.00 & 10.75 & 10.50 & 11.00 & 10.50 & 10.00 \\
\hline \multirow{3}{*}{$\begin{array}{l}\text { Kekerasan } \\
\left(\mathrm{g} / \mathrm{mm}^{2}\right)\end{array}$} & Mentah & 176.52 & 170.83 & 153.16 & 144.74 & 168.77 & 132.86 & 121.01 \\
\hline & Matang & 169.64 & 158.09 & 132.86 & 99.45 & 148.56 & 109.56 & 104.96 \\
\hline & Masak & 127.72 & 127.72 & 127.28 & 119.11 & 96.12 & 86.27 & 84.77 \\
\hline
\end{tabular}

Angka dalam tabel adalah rata-rata dari 3 ulangan 
Tabel 3. Pengaruh tingkat kematangan dan suhu penyimpanan terhadap nilai kesukaan warna, aroma dan tekstur buah terong belanda selama penyimpanan

\begin{tabular}{|c|c|c|c|c|c|c|c|c|}
\hline \multirow{3}{*}{$\begin{array}{l}\text { Parameter } \\
\text { Mutu }\end{array}$} & \multirow{3}{*}{$\begin{array}{l}\text { Tingkat } \\
\text { Kematangan }\end{array}$} & \multicolumn{7}{|c|}{ Lama Penyimpanan (Hari) } \\
\hline & & \multicolumn{4}{|c|}{ Suhu $10^{\circ} \mathrm{C}$} & \multicolumn{3}{|c|}{ Suhu $28 \pm 2{ }^{\circ} \mathrm{C}$} \\
\hline & & 0 & 5 & 10 & 15 & 5 & 10 & 15 \\
\hline \multirow[t]{3}{*}{ Warna } & Mentah & 1.20 & 1.50 & 1.60 & 1.75 & 1.50 & 1.65 & 1.85 \\
\hline & Matang & 3.10 & 3.20 & 3.30 & 3.50 & 3.30 & 3.45 & 3.80 \\
\hline & Masak & 4.20 & 4.50 & 4.60 & 4.75 & 4.35 & 4.45 & 5.00 \\
\hline \multirow[t]{3}{*}{ Aroma } & Mentah & 2.70 & 2.50 & 1.85 & 1.65 & 2.55 & 1.95 & 1.60 \\
\hline & Matang & 3.50 & 3.40 & 3.05 & 2.60 & 3.35 & 2.85 & 2.45 \\
\hline & Masak & 3.80 & 3.50 & 3.20 & 2.50 & 3.30 & 3.00 & 2.30 \\
\hline \multirow[t]{3}{*}{ Tekstur } & Mentah & 3.40 & 3.30 & 3.05 & 2.85 & 3.10 & 2.60 & 2.30 \\
\hline & Matang & 4.05 & 4.00 & 3.75 & 3.65 & 3.90 & 3.05 & 2.30 \\
\hline & Masak & 4.25 & 4.35 & 3.95 & 3.70 & 4.25 & 2.80 & 2.05 \\
\hline
\end{tabular}

Angka dalam tabel adalah rata-rata dari 3 ulangan

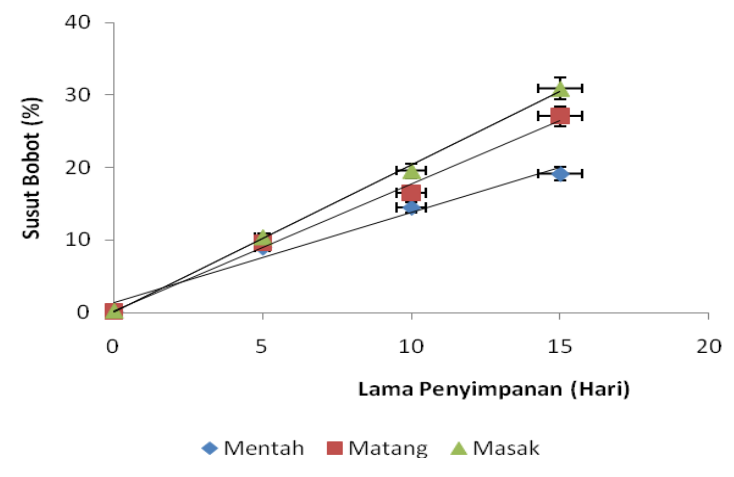

(a)

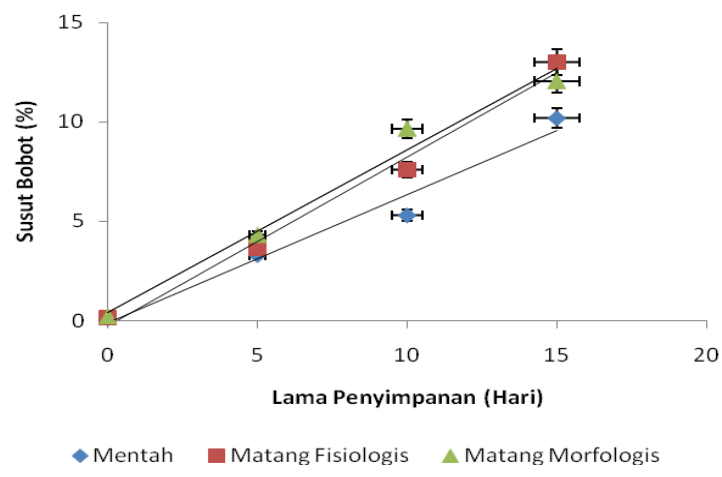

(b)

Gambar 2. Perubahan susut bobot buah terong belanda selama penyimpanan suhu $28 \pm 2{ }^{\circ} \mathrm{C}$ (a) dan suhu $10^{\circ} \mathrm{C}$ (b) pada 3 tingkat kematangan buah. Data merupakan rataan dari 3 ulangan dan error bar menunjukkan LSD 0,05.

\section{Kadar Vitamin C, Total Asam dan Total Padatan Terlarut}

Selama penyimpanan, tidak terdapat perbedaan yang nyata pada kandungan vitamin $\mathrm{C}$ dan total padatan terlarut pada ketiga tingkat kematangan buah baik yang disimpan pada suhu 10 ${ }^{\circ} \mathrm{C}$ maupun suhu ruang. Tetapi untuk total asam terdapat perbedaan yang nyata pada nilai total asam selama penyimpanan pada ketiga tingkat kematangan buah baik yang disimpan pada suhu 10 ${ }^{\circ} \mathrm{C}$ maupun suhu ruang seperti terlihat pada Gambar 3.

Vitamin C merupakan komponen gizi yang penting untuk buah termasuk terong belanda.
Kerusakan vitamin $\mathrm{C}$ berhubungan dengan aktivitas enzim ascorbic acid oxidase yang terdapat dalam jumlah lebih tinggi pada buah yang masak (Chempakam, 1983). Penurunan kandungan asam dapat terjadi karena terjadinya konversi asam membentuk gula setelah buah lewat matang (Wills et al., 1981). Terjadinya penurunan total asam selama penyimpanan terong belanda juga diperoleh pada penelitian El-Zeftawi et al.(1988). Peningkatan kandungan padatan terlarut disebabkan oleh perubahan polisakarida (pati, pektin dan hemiselulsoa) menjadi gula terlarut sederhana (Wills et al., 1981). 


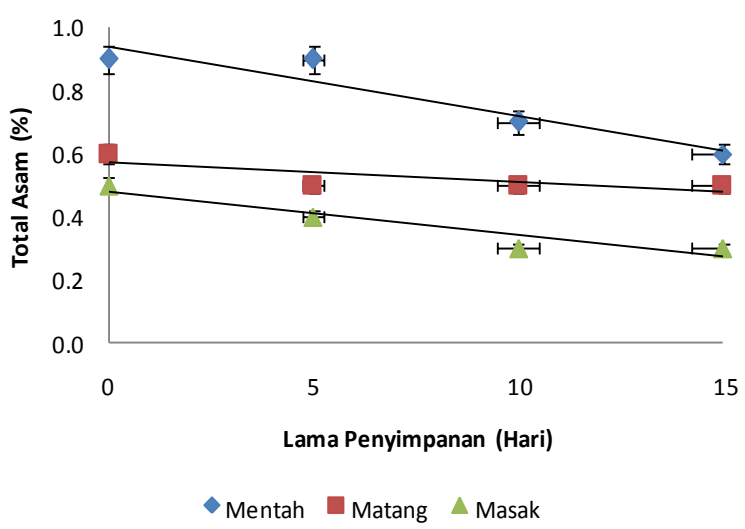

(a)

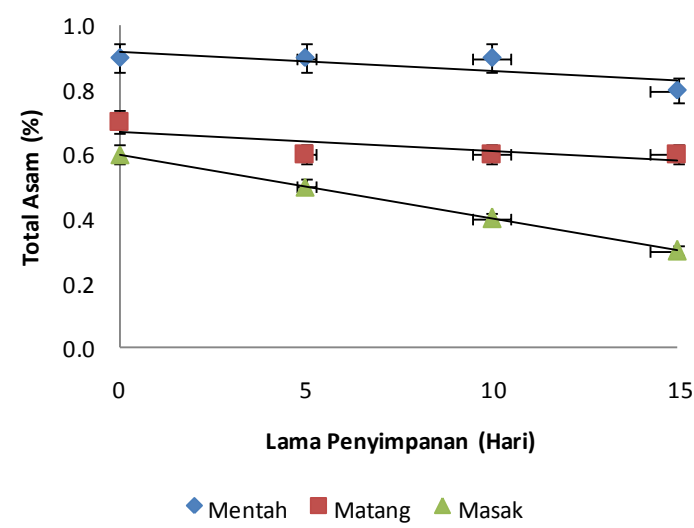

(b)

Gambar 3. Perubahan total asam buah terong belanda selama penyimpanan suhu $28 \pm 2{ }^{\circ} \mathrm{C}$ (a) dan suhu $10{ }^{\circ} \mathrm{C}$ (b) pada 3 tingkat kematangan buah. Data merupakan rataan dari 3 ulangan dan error bar menunjukkan LSD 0.05 .

\section{Kekerasan}

Tingkat kematangan dan suhu penyimpanan memberikan perbedaan yang nyata terhadap nilai kekerasan buah, tetapi lama penyimpanan tidak memberikan pengaruh yang berbeda nyata meski terjadi penurunan nilai kekerasan pada ketiga tingkat kematangan buah selama penyimpanan baik pada suhu ruang maupun suhu dingin. Penurunan nilai kekerasan menunjukkan terjadinya pelunakan pada buah. Selama proses pemasakan buah akan terjadi perubahan kandungan pektin oleh aktivitas enzim yang menyebabkan buah menjadi lunak (Heatherbell et al., 1982). Hasil yang sama juga diperoleh dari penelitian Mwithiga et al. (2007) dan Nunes et al. (2006).

\section{Skor Warna dan Nilai kesukaan Tekstur dan Aroma}

Pada Tabel 3 dapat dilihat bahwa warna dari buah terong belanda yang dipanen pada saat buah masih mentah < 3 (warna hijau hingga hijau kekuningan) hingga 15 hari penyimpanan, sedangkan pada buah yang dipanen pada saat matang nilai warna akan berubah dari merah kekuningan (skor 3) hingga mendekati merah (skor 4) setelah 15 hari penyimpanan pada suhu ruang dan suhu dingin. Nilai kesukaan terhadap aroma dan tekstur dari buah yang matang dan masak masih disukai (skor 3-4), hingga hari ke-10 penyimpanan pada suhu ruang dan hari ke-15 pada suhu penyimpanan $10^{\circ} \mathrm{C}$.

Selama proses pemasakan buah terjadi perubahan warna kulit buah terong belanda dari hijau menjadi merah, sehingga warna kulit dapat digunakan sebagai indikator pematangan pada buah terong belanda. Perubahan warna ini terjadi akibat degradasi klorofil dan sintesa pigmen antosianin (El-Zeftawi et al., 1988).

Aroma buah terbentuk selama proses pematangan buah. Pada penyimpanan suhu ruang, maka semakin lama penyimpanan nilai kesukaan terhadap aroma juga akan semakin menurun seperti dapat dilihat pada Gambar 4 (a), tetapi pada suhu 10 ${ }^{\circ} \mathrm{C}$, tidak ada perbedaan yang nyata dari nilai aroma buah selama penyimpanan pada ketiga tingkat kematangan buah. Perombakan bahan-bahan organik kompleks yang terjadi selama proses respirasi akan menghasilkan gula-gula sederhana dan asam-asam organik yang akan mempengaruhi aroma dari buah (Wills et al., 1981; Heatherbell et al., 1982).

Pada penyimpanan suhu ruang, maka semakin lama penyimpanan nilai tekstur akan semakin menurun seperti dapat dilihat pada Gambar 4(b), sedangkan pada suhu $10{ }^{\circ} \mathrm{C}$, tidak ada perbedaan yang nyata dari nilai tekstur buah selama penyimpanan. Panelis menyukai tekstur yang lunak dari buah terong belanda, tetapi pada suhu ruang setelah 10 hari penyimpanan tekstur buah sudah sangat lunak sehingga nilai kesukaan panelis menjadi rendah. 


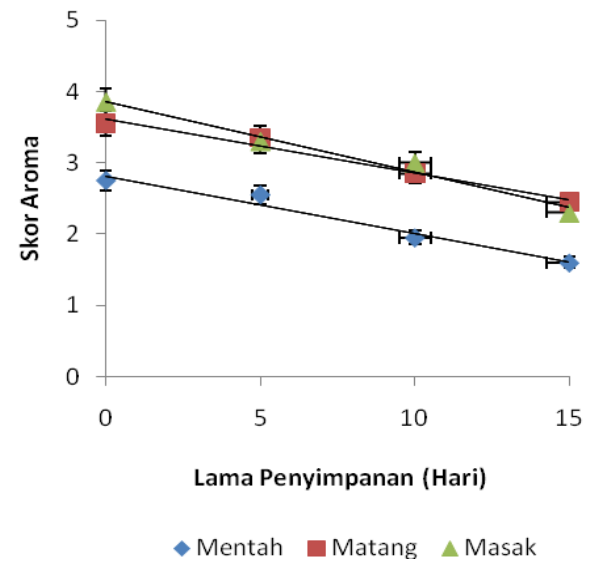

(a)

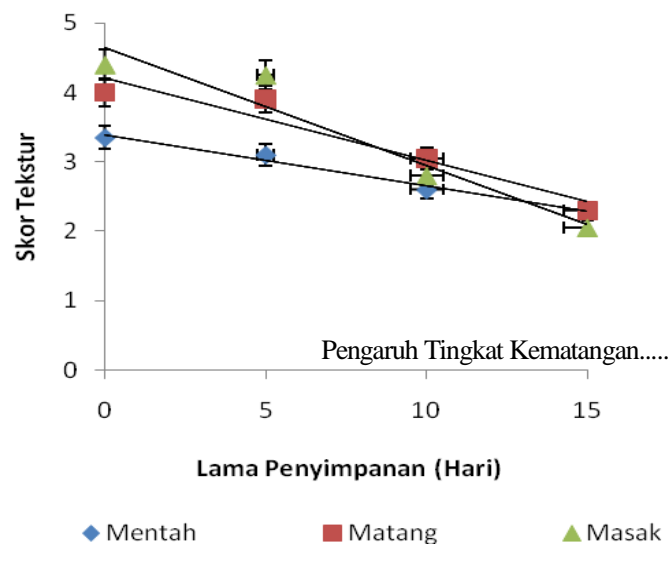

(b)

Gambar 4. Perubahan nilai kesukaan terhadap aroma (a) dan tekstur (b) buah terong belanda selama penyimpanan suhu $28 \pm 2{ }^{\circ} \mathrm{C}$ pada 3 tingkat kematangan buah. Data merupakan rataan dari 3 ulangan dan error bar menunjukkan LSD 0.05 .

\section{KESIMPULAN}

1. Laju respirasi buah tertinggi diperoleh pada buah yang matang dan terendah terdapat pada buah yang masak. Selama penyimpanan tidak terdapat peningkatan laju respirasi yang mencolok pada buah dengan tingkat kematangan mentah dan masak, baik pada penyimpanan suhu ruang maupun suhu $10{ }^{\circ} \mathrm{C}$, sehingga buah terong belanda dapat digolongkan ke dalam buah non klimakterik.

2. Pematangan buah terong belanda berhubungan dengan peningkatan total padatan terlarut, serta penurunan total asam, kandungan vitamin $\mathrm{C}$ dan kekerasan buah. Selama proses pematangan buah terong belanda terjadi perubahan warna kulit buah dari hijau menjadi merah hingga merah kecoklatan, serta perubahan tekstur dari keras menjadi lunak, sehingga warna kulit dan kekerasan dapat dijadikan indikator pematangan buah terong belanda.

3. Berdasarkan perubahan fisik dan kimia yang terjadi selama pematangan, maka buah terong belanda sebaiknya dipanen pada saat matang, karena pada stadia ini mutu buah dapat dipertahankan hingga hari ke-15 penyimpanan pada suhu $10{ }^{\circ} \mathrm{C}$ dan hari ke-10 pada penyimpanan suhu ruang.

\section{DAFTAR PUSTAKA}

AOAC, 1995. Official of Analysis of the Association of Official Analytical Chemistry. AOAC Inc, Arlington.

Azzolini, M., A.P. Jacomie, I.U. Bron, R.A. Kluge M.A. Schiavinato. 2005. Ripening of "Pedro Sato" guava : Study on its climacteric or nonclimacteric nature. Braz.J.Plant Physiol. 17(3):299-306.

Chempakam, B. 1983. Distribution of ascorbic acid oxidase activity in the developing cashew apple (Anacardium occidentale L.) J. Hort. Sci. 58:447-448.

Deily, K.R. and S.S.H.Rizvi, 1981. Optimization of parameter for packaging of fresh peaches in polymeric films. J. Food Sci. 109 (4) : 584587.

El-Zeftawi, B.M., L. Brohier, L. Dooley, F.H. Goubran, R. Holmes, B.Scott. 1988. Some maturity indices for tamarillo and pepino fruits. J. Hort. Sci. 63:163-169.

Gayosso-Garcia Sancho, L.E., E.M. Yahia, M.A. Martinez-Tellez, G.A.Gonzalez-Aguilar. 2010. Effect of maturity stage of papaya Maradol on physiological and biochemical parameters. Am. J. of Agric. and Biol. Sci. 5(2):194-203. 
Gupta, N., Jawandha, S.K., 2010. Influence of maturity stage on fruit quality during storage of "Earli Grande" Peaches. Not Sci Biol 2 (3) : 96-99. www.notulaebiologicae.ro. (10 November 2010).

Heatherbell, D.A., M.S. Reid, R.E.Wrolstad. 1982. The tamarillo : chemical composition during growth and maturation. New Zealand J.Sci. 25:239-243.

Kader AA. 2001. "Tamarillo: Recommendation for maintaining Post harvest Quality" Department of Phonology-University of California, Davis. 7 Februari 2001. http://www.ucdavis.edu. (10 November 2010).

Karki, D.B. 2005. Effect of harvesting states on the quality of tomato (Lycopersicum esculentum Mill CV.Avinash-2 Hybrid). Tribuvan University J.XXV(1):141-147.

Moneruzzaman, K.M., A.B.M.S.Haossain, W. Sani, M. Saifuddin. 2008. Effect of stages of maturity and ripening conditions on biochemical characteristics of tomato. Am. J. Biochem. and Biotechnol. 4(4):336-344.

Mwithiga, G., M.I. Mukolwe, D. Shitanda, P.N. Karanja. 2007. Evaluation of the effect of ripening on the sensory quality and properties of tamarillo (Cypomandra betacea) fruits. J. of Food Eng. 79(1): 117-123.

N'Dri, D., L. Calani, T. Mazzeo, F. Scazzina, M. Rinaldi, D. Del Rio, N. Pellegrini, F.Brighenti. 2010. Effects of different maturity stages on antioxidant content of ivorian guagnan (Solanum indicum L.) berries. Molecules 15: 7125-7138. www.mdpi.com/journal/molecules. Maret 2011).
Nunes, M.C.N., J.P. Emond, J.K.Brecht. 2006. Brief deviation from set point temperatures during normal airport handling operations negatively affect the quality of papaya (Carica papaya) fruit. Postharv. Biol.Technol.41:328-340.

Ramin,A.A., F. Tabatabaie. 2003. Effect of various maturity stages at harvest on storability of persimmon fruits (Diospyros kaki L.). J. Agric. Sci. Technol. 5:113-123.

Ranganna, S., 1978. Manual of Analysis of Fruit and Vegetable Products. Mc Graw Hill Publishing Co Ltd., New Delhi.

Riviera-Lopez, J.F. Vazquez-Ortiz, J.F. AyalaZavala, R. Sotelo-Mundo, G.A.GonzalesAguilar. 2005. Cutting shape and storage temperature affect overall quality of fresh-cut papaya cv.Maradol. J.Food Sci. 70:482-489.

Sudarmadji, S.B., B. Haryono, Suhardi. 1989. Prosedur Analisa untuk Bahan Makanan dan Pertanian. Liberty, Yogyakarta.

Wills, R.H., T.H. Lee, D. Graham, Mc. Gkasson, W.B. Hall, 1981. Postharvest, An Introduction to The Physiology and Handling of Fruits and Vegetables. New South Wales University Press, Kensington, Australia.

Winarno, F.G., M.A. Wirakartakusuma. 1981. Fisiologi Lepas Panen. Sastra Hudaya, Jakarta. 